\title{
Efficient Maternal to Neonate Transfer of Neutralizing Antibodies after SARS-CoV-2 Vaccination with BNT162b2: A Case-Report and Discussion of the Literature
}

\author{
Jonathan Douxfils ${ }^{1,2, *(\mathbb{D}}$, Constant Gillot ${ }^{2}\left(\mathbb{D}\right.$, Émilie De Gottal ${ }^{3}$, Stéphanie Vandervinne ${ }^{4}$, Jean-Louis Bayart ${ }^{5}$, \\ Jean-Michel Dogné ${ }^{2}$ and Julien Favresse ${ }^{2,6}$ \\ 1 Qualiblood s.a., 5000 Namur, Belgium \\ 2 Namur Thrombosis and Hemostasis Center, Namur Research Institute for Life Sciences, \\ Department of Pharmacy, Faculty of Medicine, University of Namur, 5000 Namur, Belgium; \\ constant.gillot@unamur.be (C.G.); jean-michel.dogne@unamur.be (J.-M.D.); j.favresse@labstluc.be (J.F.) \\ 3 Département de Gynécologie, Centre Hospitalier Régional de Huy, 4500 Liège, Belgium; \\ emilie.degottal@gmail.com \\ 4 Laboratoire de Biologie Clinique, Centre Hospitalier Régional Huy, 4500 Liège, Belgium; stevdv25@gmail.com \\ 5 Department of Laboratory Medicine, Clinique Saint-Pierre Ottignies, 1340 Ottignies, Belgium; \\ jean-louis.bayart@cspo.be \\ 6 Department of Laboratory Medicine, Clinique Saint-Luc Bouge, 5004 Namur, Belgium \\ * Correspondence: jonathan.douxfils@unamur.be; Tel.: +32-81-72-42-91
}

\section{check for} updates

Citation: Douxfils, J.; Gillot, C.; De Gottal, É.; Vandervinne, S.; Bayart,

J.-L.; Dogné, J.-M.; Favresse, J.

Efficient Maternal to Neonate

Transfer of Neutralizing Antibodies after SARS-CoV-2 Vaccination with BNT162b2: A Case-Report and Discussion of the Literature. Vaccines 2021, 9, 907. https://doi.org/ $10.3390 /$ vaccines 9080907

Academic Editor: Laurent Dacheux

Received: 23 July 2021

Accepted: 13 August 2021

Published: 15 August 2021

Publisher's Note: MDPI stays neutral with regard to jurisdictional claims in published maps and institutional affiliations.

Copyright: (c) 2021 by the authors. Licensee MDPI, Basel, Switzerland. This article is an open access article distributed under the terms and conditions of the Creative Commons Attribution (CC BY) license (https:/ / creativecommons.org/licenses/by/ $4.0 /)$.

\begin{abstract}
This case reports on the successful maternal to fetal transfer of neutralizing antibodies after vaccination with BNT162b2 in a pregnant woman at 25 weeks of gestation. The levels of neutralizing antibodies were approximately 5 -fold higher in the umbilical cord than in the maternal blood while the level of total antibodies showed only a 2 -fold increase. This suggest that the antibodies that crossed the syncytiotrophoblast cell barrier have specific characteristics that correlate to functional neutralizing capacity. Although pregnant and lactating women have been excluded from clinical trials for several reasons including ethical concerns about fetal exposure, accumulating evidence has now revealed that these vaccines are safe and efficient for both the fetus and the woman. Vaccination against COVID-19 in pregnancy is vital to control disease burden and to decrease morbidity in the ante-, peri- and post-natal periods. Inclusion of pregnant women in research programs for the development of SARS-CoV-2 vaccines should be mandatory to provide this population with the equitable benefits of vaccine research.
\end{abstract}

Keywords: neonates; infant; COVID-19; vaccine; antibodies; pregnancy; immunity

\section{Introduction}

Before the vaccine rollout, multiple cohort studies documented that pregnant woman were more susceptible to severe COVID-19 compared to age-matched nonpregnant women [1-3]. This is in line with the initial expectations, which stated that according to immunologic and cardiopulmonary adaptations occurring during pregnancy, the risk of severe illness from respiratory infections typically increases [4]. A systematic review of 60 studies on SARS-CoV-2 in pregnancy reported that severe illness occurred in up to $18 \%$ of pregnant patients and critical disease complicated up to $5 \%$ of the cases, comparable to rates observed in the general population [5]. Nevertheless, despite recommendations from public health advocates for pregnant women including the Center for Disease Control and Prevention (CDC), the American College of Obstetricians and Gynecologists (ACOG), and the American Academy of Pediatrics, pregnant or breastfeeding women have been excluded from clinical trials during the development of existing COVID-19 vaccines [6-12]. This causes large gaps in understanding the safety and efficacy of these vaccines in this population, which can be definitively detrimental to 
vaccine acceptance. Although data are emerging documenting the efficacy and the safety of these vaccines [13] and although guidance from these data recommend vaccination in pregnant and breastfeeding women, [14-16] getting vaccinated during pregnancy mainly remains a personal choice. Thus, the acceptance of COVID-19 vaccination in pregnancy is an important concern. According to a survey study, the COVID-19 vaccine acceptance rate during pregnancy was $58.4 \%$, a rate which is consistent with the acceptance rate of other recommended vaccines in pregnancy but that is not sufficient to avoid deleterious cases of neonate infection due to maternal to fetal transmission or infection during the early stages of life $[17,18]$.

Both neonates and pregnant women are particularly susceptible to respiratory infections, including influenza and respiratory syncytial virus (RSV) [19-21], and recent data demonstrate that a greater proportion of neonates and infants have severe or critical illness upon SARS-CoV-2 infection compared to older children [22-24]. Rare cases of vertical transmission have been reported in neonates [5], but histopathological changes in the placenta have suggested that the inflammatory nature of SARS-CoV-2 infection during pregnancy could cause adverse obstetric and neonatal events $[25,26]$. The risks of SARS-CoV-2 infection during pregnancy are preterm delivery, preeclampsia, emergency cesarian delivery, and neonatal complications including respiratory distress or pneumonia, disseminated intravascular coagulation, asphyxia, and perinatal deaths [27,28]. In addition, placental injury may increase the risk of long-term adverse neurodevelopmental, as is the case for other conditions that affect the placenta through the release of proinflammatory cytokines such as interleukin-6, which leads to the activation of Thelper cell 17 [29].

Neonates rely on the transfer of maternal immunoglobulin $\mathrm{G}(\mathrm{IgG})$ across the placenta for protection against pathogens, and vaccination aims to mimic the presence of pathogens to stimulate the maternal immune response. Data from the literature show that maternal to neonatal transfer of anti-SARS-CoV-2 antibodies is efficient although the maternal to fetal transfer ratio of IgG antibodies may differ depending on gestational age and the type of immunization, i.e., disease- or vaccine-induced [30-33]. There is also a significant improvement in the transfer of spike specific IgG into the umbilical cord with the time from second dose, suggesting that time from vaccination may be an important determinant of the transfer rates of specific IgG subpopulations following immunization in pregnancy [32]. Despite reassuring data, the neutralizing capacity of these transferred antibodies was not assessed $[30,32,33]$.

This case-report assessed the neutralizing capacity of umbilical cord blood compared to maternal blood in addition to conventional serological assay in a woman who received ta two-dose regimen of BNT162b2 during the antenatal period. To appreciate the magnitude of the antibody response of this dyad, a comparison with an age-matched cohort will also be done.

\section{Case Description and Methods}

A 28-year-old pregnant woman received her first dose of BNT162b2 mRNA COVID-19 vaccine (Pfizer-BioNTech, Mainz, Germany) at 25 weeks of gestation. The second was administered at 30 weeks. No problem was reported during the antenatal period, and no severe adverse events were reported after the vaccination. The patient only complained headache and tiredness the day after the second dose, which resolved with the administration of paracetamol twice a day. The delivery was planned to be on the 4th of July but occurred 8 days earlier, on the 26th of June at the Centre Hospitalier Régional (CHR) of Huy (Liège, Belgium), 90 days after the administration of the first vaccine dose. No delivery complications were reported, and all of the parameters of the newborn were normal. At 4 weeks, the newborn was still doing well. On the day of delivery, umbilical cord blood was collected as well as maternal blood to permit comparison of the level of SARS-CoV-2 neutralizing antibodies.

To compare the results obtained with the umbilical cord and maternal blood samples, 13 non-pregnant women of a similar age (i.e., 25 to 35 years of age) with no history of 
previous SARS-CoV-2 infection (i.e., no documented positive RT-PCR and the absence of anti-nucleocapsid antibodies), were included. These vaccinated controls were recruited at the Clinique Saint-Luc Bouge (Namur, Belgium) due to their participation in the CROVAX HCP study, a study which has already been described in detail elsewhere [34-36]. All of the participants provided informed consent prior to specimen and data collection. The study was approved by a central ethical committee (EudraCT registration number: 2020-006149-21).

Blood samples were collected in SST ${ }^{\mathrm{TM}}$ II advanced tubes (BD Vacutainer, Plymouth, UK) and were processed according to the manufacturer recommendations to obtain serum. Serum samples were then aliquoted and were stored at $-20^{\circ} \mathrm{C}$ until analysis. Antibodies against the SARS-CoV-2 nucleocapsid (anti-NCP; Elecsys Anti-SARS-CoV-2 NCP total qualitative ECLIA, Roche Diagnostics, Machelen, Belgium) and the receptor binding domain of the S1 subunit of the spike protein (anti-S; Elecsys anti-SARS-CoV-2 spike total quantitative ECLIA, Roche Diagnostics) were measured at each time point. Results above $0.8 \mathrm{U} / \mathrm{mL}$ (manufacturer's cut-off) or 0.165 COI (cut-off index as found previously [37]) for anti-S and anti-NCP antibodies, respectively, were considered positives.

Neutralizing capacity was estimated by performing a surrogate virus neutralization test (sVNT) [38]. The iFlash-2019-nCoV NAbs assay (performed on an iFlash1800 analyzer from Shenzhen YHLO Biotech Co., Ltd. (Shenzhen, China)) is a one-step competitive paramagnetic particle chemiluminescent immunoassay (CLIA) for the quantitative determination of 2019-nCoV NAbs in human serum and plasma. The assay detects NAbs that block the binding of RBD and ACE2. First, NAbs (if present) react with the RBD antigen coated on paramagnetic microparticles to form a complex. Second, the acridinium-esterlabeled ACE2 conjugate is added to competitively bind to the RBD-coated particles that were not neutralized by the NAbs (if present) from the sample, and these form another reaction mixture. Under a magnetic field, magnetic particles are adsorbed to the wall of the reaction tube, and unbound materials are washed away by the wash buffer. The resulting chemiluminescent reaction is measured in relative light units (RLUs), with an inverse relationship between the amount of NAbs and the RLU value being detected. A result $<10.0$ arbitrary unit (AU) $/ \mathrm{mL}$ is considered negative, and a result $>10.0 \mathrm{AU} / \mathrm{mL}$ is considered positive (according to the manufacturer's information). The neutralizing capacity was also confirmed using a pseudovirus neutralization test, as previously described [38]. Samples are considered to be neutralizing if the dilution factor provides a $50 \%$ diminution of the relative infectivity that is superior to 1:20. The agreement of the sVNT assay with the pVNT was found to be $97.2 \%$ [38].

\section{Results and Discussion}

The total anti-RBD titers of the maternal and the umbilical cord blood were $1120 \mathrm{U} / \mathrm{mL}$ and $2349 \mathrm{U} / \mathrm{mL}$ compared to $1747 \mathrm{U} / \mathrm{mL}$ (geometric mean; 95\%CI, 1231-2438 U/mL) in the control group at the identical time point, i.e., 90 days post-vaccination. The NAbs titers were 163 and $906 \mathrm{AU} / \mathrm{mL}$ for the maternal and the umbilical cord blood, respectively, compared to $427 \mathrm{AU} / \mathrm{mL}$ (geometric mean; $95 \% \mathrm{CI}, 222-820 \mathrm{AU} / \mathrm{mL}$ ) for the control group at 90 days post-vaccination. The maternal to fetal transfer ratio was 2.10 for total anti-RBD antibodies and 5.56 for NAbs. A summary of the results is presented in Table 1 and Figure 1. The neutralizing capacity of the maternal and umbilical cord blood was confirmed by the pVNT, with both samples having higher dilution factors than 1:20 to half of the relative infectivity. 
Table 1. Summary of serological results obtained from the maternal and the umbilical cord blood samples. For pVNT, the highest the dilution factor, the stronger the neutralizing capacity.

\begin{tabular}{ccccc}
\hline Serum Samples & Anti-N Titer (U/mL) & Anti-S Titer (U/mL) & sVNT (AU/mL) & pVNT (Dilution Factor) \\
\hline Maternal & $<0.165$ (negative) & 1120 & 162.9 & $1 / 40$ (positive) \\
\hline Umbilical cord blood & $<0.165$ (negative) & 2349 & 906.4 & $1 / 60$ (positive) \\
\hline $\begin{array}{c}\text { Maternal to fetal transfer } \\
\text { ratio }\end{array}$ & $/$ & 2.10 & 5.56 & $1.50 \ddagger$ \\
\hline
\end{tabular}

${ }^{\dagger}$ Ratio is defined as the results of umbilical cord blood divided by maternal blood. ${ }^{\ddagger} \mathrm{pVNT}$ is not a calibrated quantitative method, and thus, the ratio is only given for information. Abbreviations: pVNT, pseudovirus neutralization test; N, nucleocapsid; NR, non-reactive; $S$, spike; sVNT, surrogate virus neutralization test.
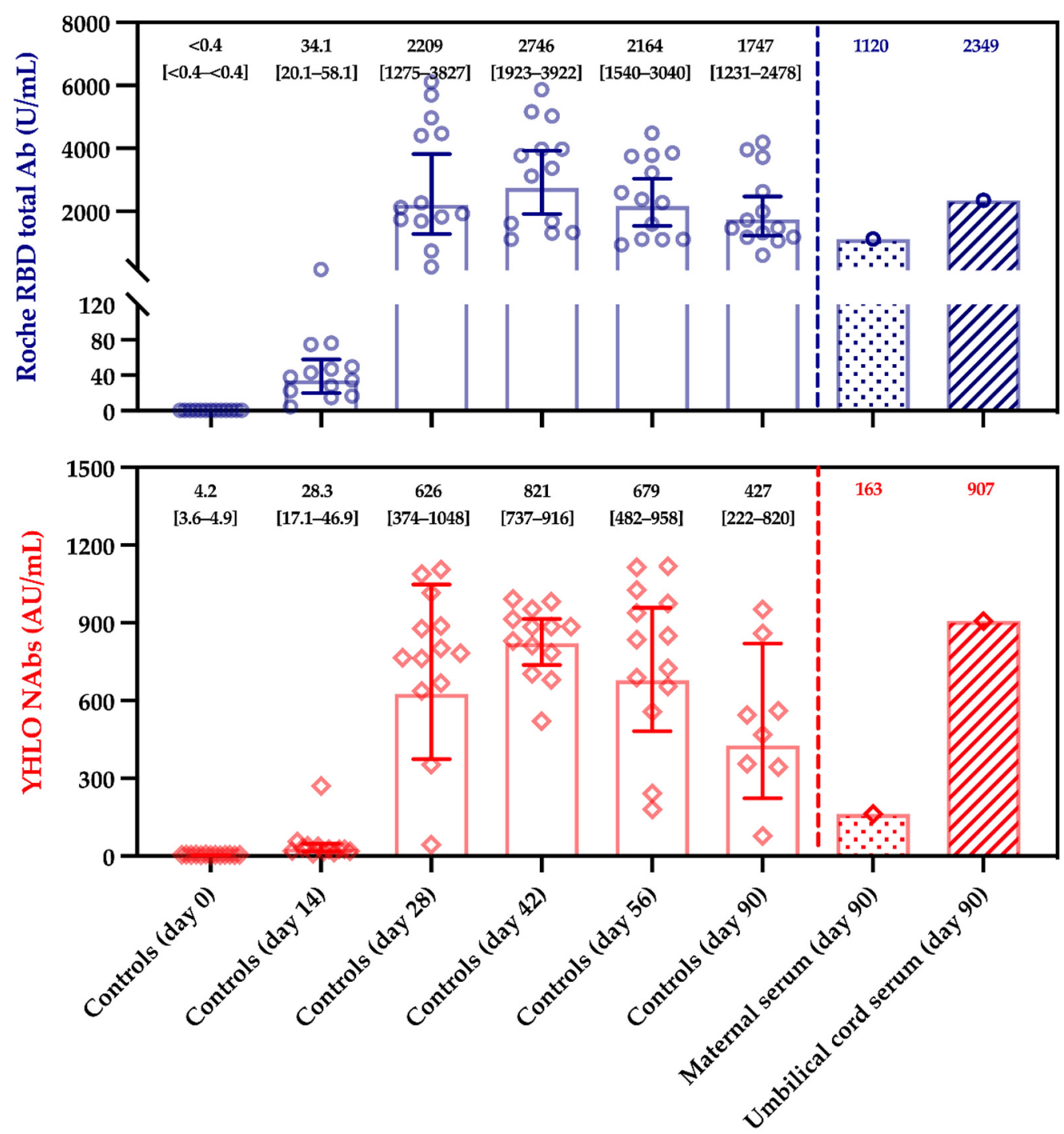

Figure 1. Serological response in controls, maternal and umbilical cord sera. Control sera selected from the CRO-VAX HCP study cohort and included 13 non-pregnant women aged from 25 to 35 (median, 30 years of age; min-max range, 25-35), without history of SARS-CoV-2 infection. Blood was collected at baseline (day 0), day 14, day 28, day 42, day 56, and day 90. Maternal and umbilical cord blood were only collected on day 90 after the vaccination, at the time of delivery. Positivity thresholds for the Roche RBD total Ab and the YHLO NAbs assays were $0.8 \mathrm{U} / \mathrm{mL}$ and $10.0 \mathrm{AU} / \mathrm{mL}$, respectively.

Recent investigations suggested that maternal SARS-CoV-2 immunization, either induced by the disease or by the vaccination, may provide neonatal protection through the transplacental transfer of antibodies [30-33]. Of particular importance was the demon- 
stration that antibody transfer is correlated with the time from vaccination to delivery, which may allow future determination of the optimal timing of COVID-19 vaccination in pregnant women [33]. Compared to the non-pregnant controls, pregnant women exhibit quite comparable vaccine-specific antibody titers, [39] although IgG titers have also been found to be slightly lower in pregnant women [13].

Zdanowski et al. observed a slightly lower maternal to fetal ratio, i.e., $1.28 \pm 0.80$ [33]. Mittal et al. also report that the mean IgG titer is similar in maternal and infant sera, but the average gestational age at first vaccine dose was 33 weeks [40]. In our case, 13 weeks separate the first vaccine dose to delivery, which could then explain the higher ratio observed. This observation was also made by Beharier et al. and Mittal et al., and the same phenomenon has been also reported after SARS-CoV-2 infection [30,40]. Thus, the data in the literature are consistent and should now permit us to draw hypothesis on when to vaccine pregnant women in order to achieve the best maternal to fetal transfer ratio. A first BNT162b2 dose administered during the second trimester could permit high umbilical cord neutralizing antibody titers that are even higher than the ones observed in the maternal blood to be obtained (Table 1).

Interestingly, our case also confirms the presence of neutralizing antibodies in the umbilical cord blood (Table 1). Another case demonstrated that the antibody subtypes, which are transferred, possess a neutralizing capacity, although a clear description of the neutralization assay that was used was not provided [41]. It is also interesting to note that total antibodies and NAbs titers in the maternal blood were at the lower range in our control cohort (Figure 1). This may be due to individual factors or may be the consequence of the maternal to fetal transfer of IgG antibodies, reducing the level of antibodies in the maternal blood.

The observations that we made in this case report following vaccination with BNT162b2 are not so surprising. For most pathogens, umbilical cord titers of IgG are higher than in maternal blood due to endosomal transport of IgG across the syncytiotrophoblast cell barrier from maternal to fetal circulation [42-44]. Among these $\mathrm{IgG}$ antibodies, galactosylated IgG1 antibodies are transferred preferentially, followed by IgG3, IgG2, and IgG4 [45]. This is potentially the result of enhanced binding to both placental FcRN and FCGR3, enabling the selective transfer of specific antibody subpopulations to most effectively arm neonates in the setting of pathogen exposure $[45,46]$. The fact that the ratio for neutralizing antibodies is higher than the one of total antibodies may also be explained by this preferential transfer of IgG1, as most serological assays used to assess the humoral response towards SARS-CoV-2 vaccination target either all types of antibodies or all IgG subtypes. Indeed, it is possible that specific Fc glycoforms can be linked to Fab specificity and subsequently to a different neutralizing capacity, as reported for influenza vaccination [47]. Thus, if a specific fraction of neutralizing galactosylated IgG subtypes is transferred from the maternal blood to the fetus, the neutralizing capacity ratio may increase more sharply than the total level of antibodies since other types of antibodies, which are not neutralizing and do not transfer trough the placenta, can compensate for the decrease of neutralizing antibodies in the maternal blood.

Interestingly, in line with the above explanations, immunization transfer may also depend on whether it is acquired after vaccination or previous infection. Indeed, some cases were reported and described inefficient maternal to fetal transfer following COVID-19 disease during pregnancy $[48,49]$. This could have been explained by Rh isoimmunization, which can compete for IgG transfer within the neonatal $\mathrm{Fc}_{\mathrm{c}}$ receptor ( $\left.\mathrm{FCRN}\right)$, but, despite high levels of anti-D antibodies, protective antibodies for other pathogens (i.e., rubeola and varicella) successfully crossed the placenta [48]. This observation can be explained, however, by changes to the Fc-glycosylation profile of the SARS-CoV-2 antibodies due to the inflammatory state generated by SARS-CoV-2 infection $[31,50]$.

This may influence the neutralizing capacity of the antibodies and may impact the transfer of immunity, especially during the third trimester $[31,47,50]$. Nonetheless, this perturbed placental transfer is probably dependent on the trimester, as observed across two 
independent third trimester-infection cohorts where normalized following second trimester infection, suggesting that inflammation-induced alterations in SARS-CoV-2-specific-glycan profiles may resolve over time from infection [31]. It remains to be known if such alterations in Fc glycosylation are also observed after vaccination, but in any case, our results and those from other groups $[30,32,33]$ strongly suggest that BNT162b2 administration in the second trimester permit the generation of a strong immune response that can be efficiently transferred to the fetus in order to protect neonates from SARS-CoV-2 infection.

Although these data have been obtained in a small number of subjects, these are quite reassuring, and the present case demonstrates that the antibody subtypes that are transferred possess high neutralizing capacity.

\section{Conclusions}

This case reports on the successful maternal to fetal transfer of neutralizing antibodies after vaccination with BNT162b2 in a pregnant woman at 25 weeks of gestation. The levels of neutralizing antibodies were approximately 5 -fold higher in the umbilical cord than in the maternal blood, while the level of total antibodies showed only a 2-fold increase. This suggests that the antibodies that crossed the syncytiotrophoblast cell barrier have specific characteristics that correlate to functional neutralizing capacity. Although pregnant and lactating woman have been excluded from clinical trials for several reasons including ethical concerns about fetal exposure, accumulating evidence has now revealed that these vaccines are safe and efficient for both the fetus and the woman. Vaccination against COVID-19 in pregnancy is vital to control disease burden and to decrease morbidity in the ante-, peri- and post-natal periods. Inclusion of pregnant women in research programs for the development of SARS-CoV-2 vaccines should be mandatory to provide this population with the equitable benefits of vaccine research.

Author Contributions: Conceptualization, J.D.; methodology, É.D.G., J.F., C.G., and S.V.; formal analysis, J.D., J.F., and C.G.; investigation, J.D., J.F., and C.G.; resources, É.D.G., J.F., C.G., and S.V.; writing — original draft preparation, J.D.; writing—review and editing, J.-L.B., É.D.G., J.-M.D., J.F., and C.G.; supervision, J.D.; project administration, J.D. All authors have read and agreed to the published version of the manuscript.

Funding: This research has been funded by the authors own funds.

Institutional Review Board Statement: The study was conducted according to the guidelines of the Declaration of Helsinki and was approved by the Ethics Committee of Clinique Saint-Luc Bouge (protocol registration number: 2020-006149-21-approved on the 14th of January 2021).

Informed Consent Statement: Informed consent was obtained from all subjects involved in the study. In addition, written informed consent has been obtained from the patient to publish this paper.

Data Availability Statement: The data presented in this study are available upon request from the corresponding author. The data are not publicly available due to ethical and privacy reasons.

Acknowledgments: The authors would like to acknowledge the mother and the neonate for their participation in this study as well as the subjects from the CRO-Vax study who served as controls. The authors would also like to thank the midwifes at the Centre Hospitalier Régional de Huy for assisting during the delivery.

Conflicts of Interest: The authors declare no conflict of interest in relation with the present study.

\section{References}

1. Zambrano, L.D.; Ellington, S.; Strid, P.; Galang, R.R.; Oduyebo, T.; Tong, V.T.; Woodworth, K.R.; Nahabedian, J.F., 3rd; AzzizBaumgartner, E.; Gilboa, S.M.; et al. Update: Characteristics of Symptomatic Women of Reproductive Age with LaboratoryConfirmed SARS-CoV-2 Infection by Pregnancy Status-United States, January 22-October 3, 2020. MMWR Morb. Mortal. Wkly. Rep. 2020, 69, 1641-1647. [CrossRef]

2. Ellington, S.; Strid, P.; Tong, V.T.; Woodworth, K.; Galang, R.R.; Zambrano, L.D.; Nahabedian, J.; Anderson, K.; Gilboa, S.M. Characteristics of Women of Reproductive Age with Laboratory-Confirmed SARS-CoV-2 Infection by Pregnancy Status-United States, January 22-June 7, 2020. MMWR Morb. Mortal. Wkly. Rep. 2020, 69, 769-775. [CrossRef] 
3. Riley, L.E. mRNA COVID-19 Vaccines in Pregnant Women. N. Engl. J. Med. 2021, 384, 2342-2343. [CrossRef] [PubMed]

4. Schwartz, D.A.; Graham, A.L. Potential Maternal and Infant Outcomes from (Wuhan) Coronavirus 2019-nCoV Infecting Pregnant Women: Lessons from SARS, MERS, and Other Human Coronavirus Infections. Viruses 2020, 12, 194. [CrossRef] [PubMed]

5. Pettirosso, E.; Giles, M.; Cole, S.; Rees, M. COVID-19 and pregnancy: A review of clinical characteristics, obstetric outcomes and vertical transmission. Aust. New Zealand J. Obstet. Gynaecol. 2020, 60, 640-659. [CrossRef]

6. Polack, F.P.; Thomas, S.J.; Kitchin, N.; Absalon, J.; Gurtman, A.; Lockhart, S.; Perez, J.L.; Perez Marc, G.; Moreira, E.D.; Zerbini, C.; et al. Safety and Efficacy of the BNT162b2 mRNA COVID-19 Vaccine. N. Engl. J. Med. 2020, 383, $2603-2615$. [CrossRef] [PubMed]

7. $\quad$ Baden, L.R.; El Sahly, H.M.; Essink, B.; Kotloff, K.; Frey, S.; Novak, R.; Diemert, D.; Spector, S.A.; Rouphael, N.; Creech, C.B.; et al. Efficacy and Safety of the mRNA-1273 SARS-CoV-2 Vaccine. N. Engl. J. Med. 2021, 384, 403-416. [CrossRef] [PubMed]

8. Sadoff, J.; Gray, G.; Vandebosch, A.; Cardenas, V.; Shukarev, G.; Grinsztejn, B.; Goepfert, P.A.; Truyers, C.; Fennema, H.; Spiessens, B.; et al. Safety and Efficacy of Single-Dose Ad26.COV2.S Vaccine against COVID-19. N. Engl. J. Med. 2021, 384, 2187-2201. [CrossRef]

9. Logunov, D.Y.; Dolzhikova, I.V.; Shcheblyakov, D.V.; Tukhvatulin, A.I.; Zubkova, O.V.; Dzharullaeva, A.S.; Kovyrshina, A.V.; Lubenets, N.L.; Grousova, D.M.; Erokhova, A.S.; et al. Safety and efficacy of an rAd26 and rAd5 vector-based heterologous prime-boost COVID-19 vaccine: An interim analysis of a randomised controlled phase 3 trial in Russia. Lancet 2021, 397, 671-681. [CrossRef]

10. Voysey, M.; Clemens, S.A.C.; Madhi, S.A.; Weckx, L.Y.; Folegatti, P.M.; Aley, P.K.; Angus, B.; Baillie, V.L.; Barnabas, S.L.; Bhorat, Q.E.; et al. Safety and efficacy of the ChAdOx1 nCoV-19 vaccine (AZD1222) against SARS-CoV-2: An interim analysis of four randomised controlled trials in Brazil, South Africa, and the UK. Lancet 2021, 397, 99-111. [CrossRef]

11. Maykin, M.M.; Heuser, C.; Feltovich, H. Pregnant people deserve the protection offered by SARS-CoV-2 vaccines. Vaccine 2021, 39, 171-172. [CrossRef]

12. Craig, A.M.; Hughes, B.L.; Swamy, G.K. Coronavirus disease 2019 vaccines in pregnancy. Am. J. Obstet. Gynecol. MFM 2021, 3 , 100295. [CrossRef] [PubMed]

13. Bookstein Peretz, S.; Regev, N.; Novick, L.; Nachshol, M.; Goffer, E.; Ben-David, A.; Asraf, K.; Doolman, R.; Sapir, E.; Regev Yochay, G.; et al. Short-term outcome of pregnant women vaccinated by BNT162b2 mRNA COVID-19 vaccine. Ultrasound Obs. Gynecol. 2021. [CrossRef] [PubMed]

14. Donders, G.G.G.; Grinceviciene, S.; Haldre, K.; Lonnee-Hoffmann, R.; Donders, F.; Tsiakalos, A.; Adriaanse, A.; Martinez de Oliveira, J.; Ault, K.; Mendling, W.; et al. ISIDOG Consensus Guidelines on COVID-19 Vaccination for Women before, during and after Pregnancy. J. Clin. Med. 2021, 10, 2902. [CrossRef]

15. Ory, S.; Veiga, A.; Horton, M.; Gianaroli, L. Joint IFFS/ESHRE statement on COVID-19 vaccination for pregnant women and those considering pregnancy. Hum. Reprod. Open 2021, 2021, hoab016. [CrossRef] [PubMed]

16. Society for Maternal-Fetal Medicine. Society for Maternal-Fetal Medicine (SMFM) Statement: SARS-CoV-2 Vaccination in Pregnancy. Available online: https://s3.amazonaws.com/cdn.smfm.org/media/2591/SMFM_Vaccine_Statement_12-1-20_(final) .pdf (accessed on 21 July 2021).

17. Razzaghi, H.; Kahn, K.E.; Black, C.L.; Lindley, M.C.; Jatlaoui, T.C.; Fiebelkorn, A.P.; Havers, F.P.; D’Angelo, D.V.; Cheung, A.; Ruther, N.A.; et al. Influenza and Tdap Vaccination Coverage Among Pregnant Women-United States, April 2020. MMWR Morb. Mortal. Wkly. Rep. 2020, 69, 1391-1397. [CrossRef]

18. Levy, A.T.; Singh, S.; Riley, L.E.; Prabhu, M. Acceptance of COVID-19 vaccination in pregnancy: A survey study. Am. J. Obstet. Gynecol. MFM 2021, 3, 100399. [CrossRef]

19. Gerretsen, H.E.; Sande, C.J. Development of respiratory syncytial virus (RSV) vaccines for infants. J. Infect. 2017, 74 (Suppl. 1), S143-S146. [CrossRef]

20. Rasmussen, S.A.; Jamieson, D.J.; Uyeki, T.M. Effects of influenza on pregnant women and infants. Am. J. Obstet. Gynecol. 2012, 207, S3-S8. [CrossRef] [PubMed]

21. Zaman, K.; Roy, E.; Arifeen, S.E.; Rahman, M.; Raqib, R.; Wilson, E.; Omer, S.B.; Shahid, N.S.; Breiman, R.F.; Steinhoff, M.C. Effectiveness of maternal influenza immunization in mothers and infants. N. Engl. J. Med. 2008, 359, 1555-1564. [CrossRef]

22. Dong, Y.; Mo, X.; Hu, Y.; Qi, X.; Jiang, F.; Jiang, Z.; Tong, S. Epidemiology of COVID-19 Among Children in China. Pediatrics 2020, 145, e20200702. [CrossRef]

23. Mithal, L.B.; Machut, K.Z.; Muller, W.J.; Kociolek, L.K. SARS-CoV-2 Infection in Infants Less than 90 Days Old. J. Pediatr. 2020, 224, 150-152. [CrossRef] [PubMed]

24. Kim, L.; Whitaker, M.; O’Halloran, A.; Kambhampati, A.; Chai, S.J.; Reingold, A.; Armistead, I.; Kawasaki, B.; Meek, J.; YouseyHindes, K.; et al. Hospitalization Rates and Characteristics of Children Aged <18 Years Hospitalized with Laboratory-Confirmed COVID-19-COVID-NET, 14 States, March 1-July 25, 2020. MMWR Morb. Mortal. Wkly. Rep. 2020, 69, 1081-1088. [CrossRef] [PubMed]

25. Richtmann, R.; Torloni, M.R.; Oyamada Otani, A.R.; Levi, J.E.; Crema Tobara, M.; de Almeida Silva, C.; Dias, L.; Miglioli-Galvao, L.; Martins Silva, P.; Macoto Kondo, M. Fetal deaths in pregnancies with SARS-CoV-2 infection in Brazil: A case series. Case Rep. Womens Health 2020, 27, e00243. [CrossRef] [PubMed]

26. Prochaska, E.; Jang, M.; Burd, I. COVID-19 in pregnancy: Placental and neonatal involvement. Am. J. Reprod. Immunol. 2020, 84, e13306. [CrossRef] 
27. Zimmermann, P.; Curtis, N. COVID-19 in Children, Pregnancy and Neonates: A Review of Epidemiologic and Clinical Features. Pediatr. Infect. Dis. J. 2020, 39, 469-477. [CrossRef]

28. Gurol-Urganci, I.; Jardine, J.E.; Carroll, F.; Draycott, T.; Dunn, G.; Fremeaux, A.; Harris, T.; Hawdon, J.; Morris, E.; Muller, P.; et al. Maternal and perinatal outcomes of pregnant women with SARS-CoV-2 infection at the time of birth in England: National cohort study. Am. J. Obstet. Gynecol. 2021. [CrossRef]

29. Estes, M.L.; McAllister, A.K. Maternal immune activation: Implications for neuropsychiatric disorders. Science 2016, 353, 772-777. [CrossRef]

30. Beharier, O.; Plitman Mayo, R.; Raz, T.; Nahum Sacks, K.; Schreiber, L.; Suissa-Cohen, Y.; Chen, R.; Gomez-Tolub, R.; Hadar, E.; Gabbay-Benziv, R.; et al. Efficient maternal to neonatal transfer of antibodies against SARS-CoV-2 and BNT162b2 mRNA COVID-19 vaccine. J. Clin. Investig. 2021, 131. [CrossRef]

31. Atyeo, C.; Pullen, K.M.; Bordt, E.A.; Fischinger, S.; Burke, J.; Michell, A.; Slein, M.D.; Loos, C.; Shook, L.L.; Boatin, A.A.; et al. Compromised SARS-CoV-2-specific placental antibody transfer. Cell 2021, 184, 628-642.e610. [CrossRef]

32. Gray, K.J.; Bordt, E.A.; Atyeo, C.; Deriso, E.; Akinwunmi, B.; Young, N.; Baez, A.M.; Shook, L.L.; Cvrk, D.; James, K.; et al. Coronavirus disease 2019 vaccine response in pregnant and lactating women: A cohort study. Am. J. Obste.t Gynecol 2021. [CrossRef] [PubMed]

33. Zdanowski, W.; Wasniewski, T. Evaluation of SARS-CoV-2 Spike Protein Antibody Titers in Cord Blood after COVID-19 Vaccination during Pregnancy in Polish Healthcare Workers: Preliminary Results. Vaccines 2021, 9, 675. [CrossRef] [PubMed]

34. Favresse, J.; Bayart, J.L.; Mullier, F.; Dogne, J.M.; Closset, M.; Douxfils, J. Early antibody response in health-care professionals after two doses of SARS-CoV-2 mRNA vaccine (BNT162b2). Clin. Microbiol. Infect. 2021. [CrossRef]

35. Favresse, J.; Bayart, J.L.; Mullier, F.; Elsen, M.; Eucher, C.; Van Eeckhoudt, S.; Roy, T.; Wieers, G.; Laurent, C.; Dogne, J.M.; et al. Antibody titres decline 3-month post-vaccination with BNT162b2. Emerg. Microbes Infect. 2021, 10, 1495-1498. [CrossRef] [PubMed]

36. Bayart, J.L.; Morimont, L.; Closset, M.; Wieers, G.; Roy, T.; Gerin, V.; Elsen, M.; Eucher, C.; Van Eeckhoudt, S.; Ausselet, N.; et al. Confounding Factors Influencing the Kinetics and Magnitude of Serological Response Following Administration of BNT162b2. Microorganisms 2021, 9, 1340. [CrossRef]

37. Favresse, J.; Eucher, C.; Elsen, M.; Tre-Hardy, M.; Dogne, J.M.; Douxfils, J. Clinical Performance of the Elecsys Electrochemiluminescent Immunoassay for the Detection of SARS-CoV-2 Total Antibodies. Clin. Chem. 2020, 66, 1104-1106. [CrossRef]

38. Favresse, J.; Gillot, C.; Di Chiaro, L.; Eucher, C.; Elsen, M.; Van Eeckhoudt, S.; David, C.; Morimont, L.; Dogné, J.-M.; Douxfils, J. Neutralizing Antibodies in COVID-19 Patients and Vaccine Recipients after Two Doses of BNT162b2. Viruses 2021, $13,1364$. [CrossRef]

39. Atyeo, C.; Deriso, E.A.; Davis, C.; Bordt, E.A.; Deguzman, R.M.; Shook, L.L.; Yonker, L.M.; Fasano, A.; Akinwunmi, B.; Lauffenburger, D.A.; et al. COVID-19 mRNA vaccines drive differential Fc-functional profiles in pregnant, lactating, and non-pregnant women. bioRxiv 2021. [CrossRef]

40. Mithal, L.B.; Otero, S.; Shanes, E.D.; Goldstein, J.A.; Miller, E.S. Cord blood antibodies following maternal coronavirus disease 2019 vaccination during pregnancy. Am. J. Obstet. Gynecol. 2021, 2225, 192-194. [CrossRef]

41. Gill, L.; Jones, C.W. Severe Acute Respiratory Syndrome Coronavirus 2 (SARS-CoV-2) Antibodies in Neonatal Cord Blood After Vaccination in Pregnancy. Obstet. Gynecol. 2021, 137, 894-896. [CrossRef]

42. Munoz, F.M.; Bond, N.H.; Maccato, M.; Pinell, P.; Hammill, H.A.; Swamy, G.K.; Walter, E.B.; Jackson, L.A.; Englund, J.A.; Edwards, M.S.; et al. Safety and immunogenicity of tetanus diphtheria and acellular pertussis (Tdap) immunization during pregnancy in mothers and infants: A randomized clinical trial. JAMA 2014, 311, 1760-1769. [CrossRef] [PubMed]

43. Martinez, D.R.; Fong, Y.; Li, S.H.; Yang, F.; Jennewein, M.F.; Weiner, J.A.; Harrell, E.A.; Mangold, J.F.; Goswami, R.; Seage, G.R., 3rd; et al. Fc Characteristics Mediate Selective Placental Transfer of IgG in HIV-Infected Women. Cell 2019, 178, 190-201.e11. [CrossRef]

44. Firan, M.; Bawdon, R.; Radu, C.; Ober, R.J.; Eaken, D.; Antohe, F.; Ghetie, V.; Ward, E.S. The MHC class I-related receptor, FcRn, plays an essential role in the maternofetal transfer of gamma-globulin in humans. Int. Immunol. 2001, 13, 993-1002. [CrossRef]

45. Vidarsson, G.; Dekkers, G.; Rispens, T. IgG subclasses and allotypes: From structure to effector functions. Front. Immunol. 2014, 5, 520. [CrossRef] [PubMed]

46. Jennewein, M.F.; Goldfarb, I.; Dolatshahi, S.; Cosgrove, C.; Noelette, F.J.; Krykbaeva, M.; Das, J.; Sarkar, A.; Gorman, M.J.; Fischinger, S.; et al. Fc Glycan-Mediated Regulation of Placental Antibody Transfer. Cell 2019, 178, 202-215.e214. [CrossRef]

47. Wang, T.T.; Maamary, J.; Tan, G.S.; Bournazos, S.; Davis, C.W.; Krammer, F.; Schlesinger, S.J.; Palese, P.; Ahmed, R.; Ravetch, J.V. Anti-HA Glycoforms Drive B Cell Affinity Selection and Determine Influenza Vaccine Efficacy. Cell 2015, 162, 160-169. [CrossRef]

48. Toner, L.E.; Gelber, S.E.; Pena, J.A.; Fox, N.S.; Rebarber, A. A Case Report to Assess Passive Immunity in a COVID Positive Pregnant Patient. Am. J. Perinatol. 2020, 37, 1280-1282. [CrossRef]

49. Zeng, H.; Xu, C.; Fan, J.; Tang, Y.; Deng, Q.; Zhang, W.; Long, X. Antibodies in Infants Born to Mothers with COVID-19 Pneumonia. JAMA 2020, 323, 1848-1849. [CrossRef] [PubMed]

50. Chakraborty, S.; Gonzalez, J.; Edwards, K.; Mallajosyula, V.; Buzzanco, A.S.; Sherwood, R.; Buffone, C.; Kathale, N.; Providenza, S.; Xie, M.M.; et al. Proinflammatory IgG Fc structures in patients with severe COVID-19. Nat. Immunol. 2021, 22, 67-73. [CrossRef] 